\title{
Dilma Rousseff e o ethos de amável coragem: o corpo no feminino
}

DOI: http://dx.doi.org/10.21165/el.v48i2.2221

\section{Renata de Oliveira Carreon'}

\section{Resumo}

No século XXI, a mulher, que já vinha tomando seu espaço, ganha destaque nas disputas eleitorais, trazendo à cena não só o discurso, mas também o corpo no feminino, fazendo com que a mulher tome seu lugar nos espaços de poder. As campanhas eleitorais, nessa nova configuração, devem, de uma só vez, produzir sentidos e convidar o eleitor a aderir àquele discurso, buscando nesse eleitor/interlocutor a validação de um mundo éthico, por meio da credibilidade ou de um poder fazer legitimado no discurso. Considerando, portanto, o ethos como uma categoria intrinsecamente atada ao discurso político, propomos, neste artigo, compreender a constituição das imagens de si de Dilma Rousseff enunciadas no feminino em posts no seu perfil oficial do Facebook e na televisão em HGPE durante a campanha de segundo turno das eleições presidenciais de 2014. Para isso, ancoramonos nos escritos de Maingueneau a partir dos pressupostos teóricos e metodológicos da Análise do discurso de orientação francesa.

Palavras-chave: análise do discurso; discurso político; ethos; campanhas eleitorais.

1 Universidade Estadual de Ponta Grossa (UEPG), Ponta Grossa, Paraná, Brasil; renatacarreon@gmail.com, https://orcid.org/0000-0003-1945-1904. 


\section{Dilma Rousseff y el ethos de amable coraje: el cuerpo en el femenino}

\section{Resumen}

En el siglo XXI, la mujer, que ya venía ganando espacio, se fue destacando en las disputas electorales, trayendo a la escena no sólo el discurso, sino que también el cuerpo en el femenino, lo que generó que la mujer ocupe su lugar en espacios de poder. Las campañas electorales, en esta nueva configuración, deben producir sentidos y al mismo tiempo invitar al elector a adherirse a ese discurso, que busca en ese elector/interlocutor la validación de un mundo éthico, por medio de la credibilidad o de un poder hacer que se legitima en el discurso. Por lo tanto, se considera el ethos como una categoría intrínsecamente ligada al discurso político, por esta razón proponemos, en este artículo, comprender la construcción de las imágenes de sí, de Dilma Rousseff, que se enunciaron en femenino en posts en su perfil oficial de Facebook y en la televisión en el Horario Gratuito de Propaganda Electoral (HGPE) durante la campaña en la segunda vuelta de las elecciones presidenciales del año 2014. Para ello, nos basaremos en los escritos de Maingueneau desde los presupuestos teóricos y metodológicos del Análisis del discurso de orientación francesa.

Palabras clave: análisis del discurso; discurso político; ethos; campañas electorales.

\section{Primeiras palavras}

As eleições, de maneira geral, implicam certa teatralidade, representação de papéis por parte dos atores políticos, o que desemboca na constituição de lugares sociais, crenças e visões de mundo. Para Barreira (1998), a longa interdição à participação da mulher nas atividades políticas impôs, por muitos anos, seu distanciamento de tais práticas. No entanto, ao longo do tempo, as mulheres passaram a ter maior presença nas atividades públicas, fazendo com que a interdição imposta à mulher no campo político fosse progressivamente eliminada. Com a conquista do espaço político, a socióloga afırma que as mulheres ritualizaram sua entrada, de forma pouco silenciosa, calcadas no discurso do rompimento de barreiras,

[...] enfatizando sua capacidade para o exercício da função em reação aos preconceitos historicamente arraigados, que associam negativamente gênero feminino e desempenho político. Se o exercício de toda candidatura política, já de saída, é portador de símbolos ou emblemas que têm por objetivo a construção de uma legitimidade, as candidaturas femininas entram no páreo com a complexidade do pedido de licença para o reconhecimento. Ao invés de comparecerem apenas com a força das disposições partidárias ou dos atributos pessoais, entram no cenário político com o estatuto de gênero: uma candidata é alguém que deve ser submetido à prova da competência. (BARREIRA, 1998, p. 105). 
Com isso, as candidaturas políticas femininas são simbolicamente representadas pelo pioneirismo, uma vez que seu discurso, fortemente ligado a questões de gênero, resultante de atribuições herdadas historicamente, padece da falta de herança. Assim, discursos, emblemas e símbolos passam a fazer parte da entrada desse sujeito no campo político, trazendo especificidades em relação às candidaturas masculinas, fazendo uso de atributos de gênero como forma de diferenciação política. Exemplo disso é o fato de o universo masculino, estereotipicamente, historicamente e socialmente, estar ligado a determinadas características físicas e morais, que ao longo de séculos de civilização impuseram a masculinidade ao homem, devido a sua capacidade de provedor enquanto caçador de mantimentos, e liderança, enquanto patriarca da família e mantenedor. 0 universo feminino, mesmo no século XXI, parece perpetuar, ao menos na política, o contra fluxo, ainda inspirando social e historicamente características de afabilidade, doçura e subserviência.

No entanto, uma característica que Barreira julga típica das candidaturas femininas refere-se à tentativa de acrescer aos seus próprios atributos pessoais as qualidades que, geralmente, compõem o universo masculino, como ser portadora de coragem, garra, força, ser uma mulher guerreira, destemida. Tais qualificações validariam o discurso de aptidão da candidata: ela está apta a chefiar o Estado, uma vez que não só possui suas qualidades próprias, mas também aquelas socialmente e historicamente associadas ao mundo "masculino", indo na contramão da construção de "sexo frágil" que circula na sociedade.

A partir disso, tendo como corpus de análise os posts no Facebook de Dilma Rousseff, bem como enunciados retirados de sua campanha na televisão, no segundo turno das eleições presidenciais de 2014, buscamos compreender a constituição do ethos da candidata à reeleição.

\section{Sobre a questão do ethos}

O conceito de ethos discursivo, lido e relido por Dominique Maingueneau, foi largamente trabalhado por disciplinas e teóricos, desde Aristóteles a Ducrot, Charaudeau, entre outros. No entanto, a concepção pessoal de ethos de Maingueneau inscreve-se nos domínios da Análise do discurso de linha francesa. O autor teoriza, operacionaliza e relê o conceito de ethos em diversos trabalhos (1997, 2004, 2008a, 2008c, 2010, 2011, 2015a, 2016; entre outros). Atualmente, grande parte da literatura em termos de ethos na Análise do discurso, de alguma forma, utiliza seus escritos para fundamentar teoricamente o empreendimento analítico.

Ao postular sobre a semântica global que rege os discursos em Gênese (2008b [1984]), Maingueneau afirma que há certas restrições a que eles estão submetidos, sendo uma dessas restrições o modo de enunciação do sujeito. Embora não tenha explicitado 
a questão do ethos, ali está retratado como "uma maneira de ser através de uma maneira de dizer" (2008b, p. 94). O autor, assim, dá início às reflexões sobre caráter e corporalidade nos quais se apoia o "tom" do enunciador": "esse 'caráter' é inseparável de uma 'corporalidade', isto é, de esquemas que definem uma maneira de 'habitar' seu corpo de enunciador e, indiretamente, de enunciatário" (2008b, p. 92).

Se, até então, a preocupação do teórico francês era postular os alicerces da noção e afastá-la dos preceitos retóricos - ligados, sobretudo, a uma persuasão que deveria despertar emoções no auditório por meio do caráter do orador, em Análise de textos de comunicação (2004 [1998]), Maingueneau define o conceito de cenas da enunciação para ligá-lo ao ethos. Tal definição, trabalhada e retrabalhada ao longo dos anos posteriores, veio mostrar-se indispensável para uma análise arqueológica de suas obras, que interliga, de maneira indissociável, diversas instâncias. Para o autor, "um texto não é um conjunto de signos inertes, mas o rastro deixado por um discurso em que a fala é encenada" (MAINGUENEAU, 2004, p. 85). "O quadro cênico" do texto, então, seria dividido em cena englobante, referente ao tipo de discurso; e cena genérica, no que diz respeito ao gênero; no entanto, não é diretamente a esse quadro cênico que se confronta o "leitor", mas às cenografias, que são ao mesmo tempo "fonte de enunciação do discurso e aquilo que ele engendra" (MAINGUENEAU, 2004, p. 87), legitimando um enunciado que, por sua vez, legitima sua cenografia. Entretanto, para Maingueneau, não basta falar apenas em cena, já que todo discurso é produto de um enunciador encarnado sustentado por uma voz, é preciso dar conta das questões de ethos, uma vez que, por meio da enunciação, revela-se a personalidade do enunciador. Destaca, ainda, mais uma vez, que o ethos está ligado a determinações físicas e psíquicas, ambas ligadas a representações sociais valorizadas ou não e que, portanto, é necessário fazer com que o co-enunciador adira fisicamente a um determinado universo de sentido:

\begin{abstract}
O poder de persuasão de um discurso consiste em parte em levar o leitor a se identificar com a movimentação de um corpo investido de valores socialmente especificados. A qualidade desse ethos remete, com efeito, à imagem desse "fiador" que, por meio de sua fala, confere a si próprio uma identidade compatível com o mundo que ele deverá construir em seu enunciado. (MAINGUENEAU, 2004, p. 99).
\end{abstract}

Assim, Maingueneau oferece uma concepção mais encarnada de ethos, deixando de lado as relações específicas com formações discursivas, entendidas em Análise do discurso como o que "pode e deve ser dito" ou como um "sistema de restrições invisíveis" (MAINGUENEAU, 2015b, p. 81) - conceito que o autor, de certa forma, abandona para aderir à questão mais geral dos posicionamentos dos sujeitos. Desse modo, o ethos passa a ser teorizado a partir de seu engendramento na cena de enunciação, o que fez com que a construção das imagens de si, acreditamos, assumisse seu papel em uma teatralidade discursiva mais do que em formações discursivas historicamente determinadas que regulam os discursos. 
É preciso ainda sublinhar que os trabalhos que mobilizam a noção de ethos pouco se importam com os ethé que "resultam da multimodalidade, em particular quando há combinação de textos e imagens" (MAINGUENEAU, 2016, p. 27). Assim, considerando as novas textualidades e regimes genéricos da Web, "em uma reflexão sobre o ethos não pode mais ser ignorada a existência de iconotextos que associam intimamente texto e imagem, com todos os problemas que levanta a hierarquização dos ethé" (MAINGUENEAU, 2016, p. 32). Desse modo, nesse último texto em que trata do ethos, o autor reflete a tendência mundial dos analistas do discurso em relação às novas textualidades impostas pelo advento da internet. Tal redimensionamento de olhar leva a uma questão fundamental que deverá ser explorada em suas obras vindouras: a questão do verbal e não verbal na produção das imagens de si.

Portanto, a noção de ethos compreende, no discurso, a constituição das imagens de si. Em se tratando de ethos, é preciso destacar seu caráter multimodal, já que sua constituição leva em conta elementos de diversas ordens, como tom, vocalidade e corporalidade. Mais do que isso, a construção do ethos leva em conta não só a dimensão verbal, mas também a não verbal. Esse caráter da categoria faz com que a constituição das imagens de si seja intrínseca ao discurso político, pois, dado que a cena de enunciação é integrante do discurso, os papéis nela empregados também são. Se de um lado se tem os atores políticos, submetidos aos efeitos de sentido de seus discursos e às imagens que carregam, de outro se tem o interlocutor, que adere a esses efeitos, a um regime de verdade e a um mundo éthico ali estabelecido. Com isso, as imagens de si criam um espaço de adesão a esses discursos, por meio da credibilidade ou de um poder fazer legitimado no discurso - afinal, o sujeito, em seu discurso, deve não só se mostrar digno de crédito, mas também que tem condições de fazer aquilo que promete, resultando em um "poder fazer" inerente ao discurso político: deve-se, a todo momento, apresentar provas de que o que se promete, enquanto candidato, será feito enquanto ocupante do cargo. Por essas razões, o interlocutor adere àquilo que faz parte de seu regime de verdade - entendido aqui como aquilo que determinado grupo social considera como um discurso verdadeiro -, àquilo que se instaura como o bom ou o certo a se fazer.

Desse modo, por um lado, o ethos dito, enquanto possível estratégia discursiva, tenta fundar um espaço de adesão que adquira votos do eleitorado - que se submete, em dada cena de enunciação, a ser o interlocutor desse ator político -, por outro, o ethos mostrado, visto por meio de vários índices verbais e não verbais, é constituído à revelia de seu sujeito, sendo fiado no discurso, e conferindo características morais àquele sujeito que serão ou não validadas. Tem-se, desse modo, que as campanhas eleitorais, que são uma grande venda de si, independentemente de intencionalidade, tratam das grandes características morais às quais o eleitorado deve ou não aderir para que o candidato seja eleito. Dessa forma, não há um sujeito vencedor das eleições, mas um conjunto de características, socialmente e historicamente, aceitas e validadas. 
Em síntese, considerando o ethos como uma categoria intimamente ligada ao discurso político - uma vez que o eleitor tende a votar mais na imagem do candidato do que no candidato em si -, acreditamos que qualquer análise que vise trabalhar com campanhas eleitorais deve levar em consideração, em maior ou menor escala - dependendo dos objetivos da investigação - uma análise das imagens de si. Pois uma análise séria que se pretenda fazer dos discursos, que leve em conta seu interdiscurso, os posicionamentos ideológicos circundantes e o gênero que lhe dá suporte, inevitavelmente recairá sobre as imagens de si que emergem desse discurso. Além disso, um olhar discursivo sobre as redes sociais, independentemente do tipo de discurso, irremediavelmente incidirá, também, sobre as questões de ethos, já que o discurso, de maneira geral, a partir do seu pertencimento a uma cena de enunciação², estará sempre ligado à construção de uma imagem de si.

\section{0 ethos de amável coragem}

Em 2014, Dilma Rousseff, a primeira presidente mulher do país, disputou a reeleição ao cargo com Aécio Neves no segundo turno, corroborando a polaridade histórica entre PT e PSDB nas eleições presidenciais brasileiras. Durante os dois primeiros anos de governo, a presidente manteve altíssimos índices de aprovação, ultrapassando Lula e Fernando Henrique em comparação ao mesmo período de seus mandatos. Entretanto, em seu primeiro ano, Dilma viu sete de seus ministros deixarem o cargo por acusações de corrupção. Assim, ao lidar com a corrupção de forma enérgica, uma parcela da população acreditava em uma "faxina ética" por parte da presidente, que viu sua popularidade crescer.

Dilma, apesar de muitos feitos históricos - como a implantação da Operação Lava Jato, responsável pela prisão de inúmeros parlamentares e empresários; encontros com diversos chefes de Estado; e o fato de ser a primeira mulher a discursar na abertura da Assembleia Geral da ONU - não conseguiu repetir o mesmo crescimento econômico de seu antecessor - que chegou a elevar em 7,5\% o PIB -, aumentando o índice de desemprego, além de que muitos nomes importantes do PT acabaram sendo acusados na Operação.

Com a credibilidade da presidente e de todo o partido em xeque, com cada vez mais políticos sendo denunciados na Lava Jato, a histórica onda de protestos populares iniciados em 2013, que exigiam melhorias no transporte, educação, saúde e o fim da corrupção, fizeram com que a popularidade da presidente caísse mais de $20 \%$. Outro grande motivo de manifestação popular foi a realização da Copa no país; reclamavam os gastos públicos excessivos com construção de estádios e superfaturamento. Na abertura da Copa das Confederações FIFA 2013, Dilma foi vaiada pela plateia. Em julho

2 "Cena de enunciação" é um conceito desenvolvido largamente por Maingueneau (2015b) para se referir ao quadro cênico da enunciação, no qual o discurso implicaria a encenação de sua enunciação, impondo, a partir de sua teatralidade, papéis a serem atribuídos aos sujeitos. 
de 2014 , a presidente volta a ser vaiada ao entregar a taça para a campeã do torneiro, a Alemanha.

Considerando os acontecimentos e a conjuntura histórica que se formaram no entorno de erros e acertos, trabalhos sociais importantes e membros do partido sendo presos, ocorreram as eleições de 2014.

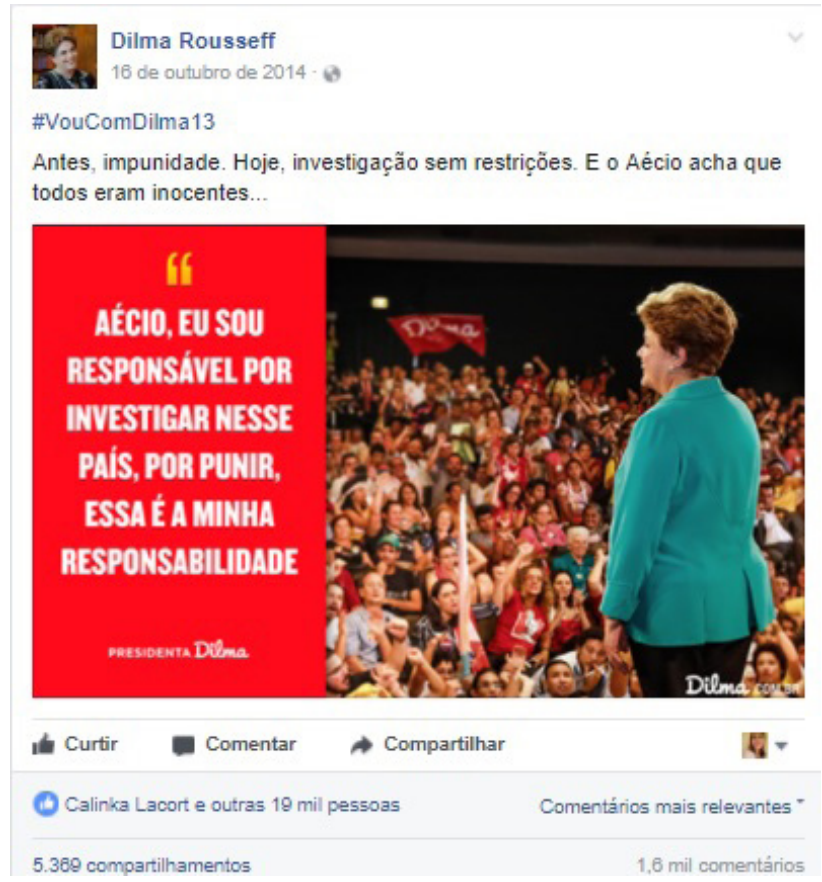

Figura 1. Post de Dilma Rousseff em 16 de outubro

Fonte: Perfil oficial no Facebook.

Para o esboço analítico que pretendemos traçar aqui, nosso primeiro post mobilizado faz parte do eixo temático da corrupção e apresenta um enunciado verbal atribuído à presidente candidata à reeleição, pois vem seguido por seu nome que, na campanha presidencial, funciona como assinatura oficial, uma espécie de insígnia garantidora de oficialidade, o que remete a processos de significação que falam sobre autenticidade, legitimidade e legalidade do que ali, no post, está asseverado e passa, então, a ser dito e expresso como um discurso sustentado pela candidata: "Aécio, eu sou responsável por investigar nesse país, por punir, essa é a minha responsabilidade". E outro, acima: "Antes, impunidade. Hoje, investigação sem restrições. E o Aécio acha que todos eram inocentes...". Ainda é preciso observar que a afırmação entre aspas, juntamente da fotografia, remete a um enunciado - e uma imagem - destacado de seu texto-fonte que, agora, passa a circular em outra materialidade. Ao produzir a mudança de suporte - de um momento específico de fala para o Facebook - o enunciado passa a ter maior 
circulação, chegando a interlocutores que não o seriam no lugar inicial de fala. Assim, é preciso ter em conta que o destacamento do enunciado, quando imposto a circular em outros suportes, sobretudo aqueles, como o Facebook, que são on-line e de alcance irrestrito - já que qualquer um com acesso à internet pode ver esse post - faz com que toda a cena de enunciação seja ressignificada, uma vez que os papéis atribuídos à cena são redistribuídos no Facebook.

Sob o signo da responsabilidade, o locutor se coloca como juiz e carrasco de investigados na Operação Lava Jato - conjunto de investigações da Polícia Federal para, inicialmente, apurar esquemas de lavagem de dinheiro -, que levou à execução de inúmeros mandados de prisão contra pessoas de vários cargos públicos e políticos. Sob a cenografia do incorruptível, daquele que não se vende e daquele que não perdoa, o ethos de coragem passa a ser fiado, afinal, em tese, aquele que é responsável por julgar não é passível de julgamento. Além disso, o discurso de coragem e valentia perpassa a cena, uma vez que só sendo portador de tais características é que o ator político poderia assumir a responsabilidade por punir aqueles que merecem, independentemente de cargo ou partido político, em uma "investigação sem restrições".

Assim é constituída a imagem do sujeito enquanto a do outro é atacada: o uso de "antes" remete a um tempo anterior indeterminado, mas que pode ser facilmente atribuído à antes do governo do PT, quando o PSDB era o responsável pela gestão, remontando a polaridade partidária de presidentes do Brasil desde 1994. Atribuindo, dessa forma, ao partido do qual faz parte seu adversário a impunidade, enquanto, por meio do dêitico "agora", o locutor marca temporalmente sua gestão, que fez "investigação sem restrições", a desqualificação do outro passa a ser constituída por meio do seu avesso: eu sou aquilo que você não é, afınal, enquanto um está caçando corruptos, o outro acreditava que estes eram inocentes. Atribuiu-se, assim, em um movimento de desqualificação do outro para adesão ao seu próprio ethos, imagens de si e do outro, uma vez que o fiador questiona o lugar que o outro ocupa em relação à corrupção, opondo sua imagem de incorruptível à passividade da ignorância. O ethos de coragem passa, então, a ser constituído, pois só por meio de fortes caracteres morais alguém pode promover tal empreendimento.

Na imagem, vê-se a candidata de frente para o povo e quase de costas para a câmera. Enquanto o enunciado está em um quadro vermelho, remetendo à cor do partido, ao lado se vê uma fotografia, possivelmente de comício. É possível visualizar muitas pessoas e Dilma, trajando verde - uma das cores da bandeira -, em um encontro de olhares, com o qual ela sorri. Tal composição imagética constitui efeitos de sentido da ordem da adesão popular: esse corpo, esse sujeito, possuem adesão, pois ali estão compondo o campo do visível. O ethos fabricado no plano imagético, como em grande parte de sua campanha, passa a ser constituído na ordem da legitimação pelo povo, que atesta e adere ao que é dito. Podemos afirmar, assim, que ao ethos dito e ao ethos mostrado de coragem, vem juntar-se este que constrói sentidos, por meio da visibilidade, do sujeito que possui apoio 
do povo, que lhe confere, por meio do caráter de identificação, o estatuto de porta-voz dele. Com isso, acreditamos, o ethos discursivo de coragem vai sendo fiado em duas vias: por meio do verbal, que atesta a coragem, e por meio do não verbal, que atesta a adesão popular ao mundo éthico daquele que, com coragem, combate a corrupção.

É nessa esteira de sentidos que temos o post de 23 de outubro:

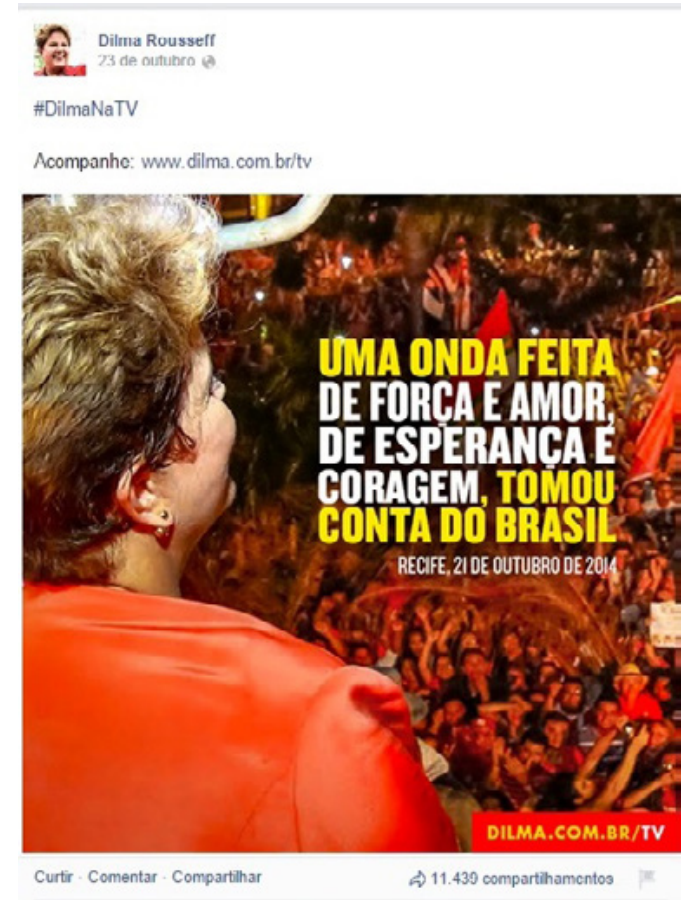

Figura 2. Post de Dilma Rousseff em 23 de outubro

Fonte: Perfil oficial no Facebook.

Nele, em branco e amarelo, se lê: "Uma onda feita de força e amor, de esperança e coragem, tomou conta do Brasil".

Na ordem do imagético, mais uma vez, temos a candidata de costas para a câmera e de frente para o público, recriando os sentidos do apoio popular que atestam o que é dito, além de um não se importar com o olhar exterior, o olhar além da câmera, como se só o que importasse fosse aquele único momento diante do povo. Bandeiras e camisetas vermelhas são vistas, corroborando a adesão do público e a imagem daquela que está ligada a ele.

O enunciado joga com palavras de campos semânticos distintos: força e amor, esperança e coragem, o que vai de encontro ao exposto anteriormente em relação à constituição do 
ethos de Dilma: se por um lado há sentidos sendo constituídos na ordem da coragem e da valentia, por outro, o apoio popular depõe a favor da capacidade de mobilização do sujeito e seu forte apelo popular. É assim que força e amor podem ser complementares em um mesmo enunciado, pois, ao mesmo tempo, há força para vencer, para combater, para lutar; por outro, há amor em relação ao povo e ao país; além disso, junto da coragem, ainda vem a esperança de dias melhores.

Para Barreira (2008, p. 143), isso ocorre em uma espécie de lógica atenuadora, na qual imagens que poderiam ser estereotipicamente negativas são suavizadas por um discurso de ternura ou suavidade:

O jogo de atenuação de imagens consiste, assim, em "contrabalancear" versões ou classificações negativas, apontadas como intransigentes ou pouco flexíveis, imputadas geralmente à esquerda, com alusões à beleza, ao amor, enfim, a símbolos mais associados a papéis femininos.

Dessa forma, o sujeito que possui os caracteres da coragem poderia ser visto como duro ou irredutível, no entanto, na tessitura de sentidos, povo, amor e esperança são mobilizados para constituir um ethos amável de coragem, um ethos ao qual o povo quer aderir por amor. Se, por um lado, como afirmou Barreira (1998), características estereotipicamente atribuídas ao universo masculino - como a coragem - são mobilizadas para validar seu discurso de aptidão, por outro, características do universo feminino - como amor, acolhimento - também são trazidas à cena. O "sexo frágil", então, passa a ser não tão frágil, pois por trás da valentia, há docilidade. Nas palavras da autora:

Outra característica, que integra uma simbologia das candidaturas de mulheres refere-se à tentativa de acrescer, aos atributos pessoais da candidata, qualidades que são comumente designadas como sendo próprias do universo masculino. Substantivos como fortaleza, coragem, garra, força e adjetivos como guerreira, destemida, corajosa são comumente usados em slogans ou músicas de campanha. Isso revela que mulheres portadoras de atributos do mundo "masculino" estão aptas a ingressar na política, ou melhor, até mais preparadas em razão da incorporação de outras qualidades que vindas de um espaço "alheio" tornariam tais atributos mais autênticos. (BARREIRA, 2008, p. 155).

Vemos, portanto, em um jogo de imagens, coragem e amor sendo elementos constitutivos do processo de fabricação do ethos e, por isso, defendemos a constituição de uma amável coragem, integrando, em um sintagma, as duas dimensões que correspondem a um imaginário popular: a força masculina e a docilidade feminina em uma só forma de governar. 
Da campanha no HGPE (Horário Gratuito de Propaganda Eleitoral), ainda podemos destacar os enunciados de 24 de outubro3:

(1) Lutei contra a ditadura. Venci a tortura, venci o câncer. O meu amor à vida, os meus ideais, as minhas paixões, a minha obsessão pelo sonho, o meu vício de esperança, me ajudaram a vencer todas as dificuldades. Agora, o que me leva adiante é minha paixão pelo Brasil, e pelo povo brasileiro.

Em (1), o locutor fia seu ethos por meio de experiências passadas que exigiram coragem: lutar contra a ditadura, vencer a tortura e o câncer. As palavras, da ordem da luta, reafirmam a constituição de sentidos em torno da coragem, pois lutou e venceu situações que poucas pessoas podem afirmar que enfrentaram. Passando a um encadeamento semântico positivo, destaca o amor à vida, a ideais, a paixões, além da obsessão pelo sonho e o vício de esperança - as palavras "obsessão" e "vício", que socialmente constituem o eixo paradigmático de ações negativas, ligadas geralmente a alguém que perde a razão em função de algo ou ao consumo exagerado de bebida ou droga, passam a engendrar ações positivas ao se ter uma obsessão pelo "sonho" e o vício de "esperança". O discurso da esperança que vence o medo e o ódio vence também todas as dificuldades e a paixão pelo Brasil e pelo povo é o que leva o locutor a continuar. Sendo assim, a coragem do sujeito que enfrentou sérias dificuldades é encadeada na mesma rede de sentidos daquele que ama o povo e ama sonhar junto dele. 0 ethos da amável coragem, portanto, é constituído em campos semânticos diversos.

O enunciado é proferido, nesse vídeo em específico, em uma situação de fala na qual o locutor serve como narrador, enquanto inúmeras cenas do e com o povo são mostradas:

3 As palavras em negrito indicam ênfase dada pelo locutor. 


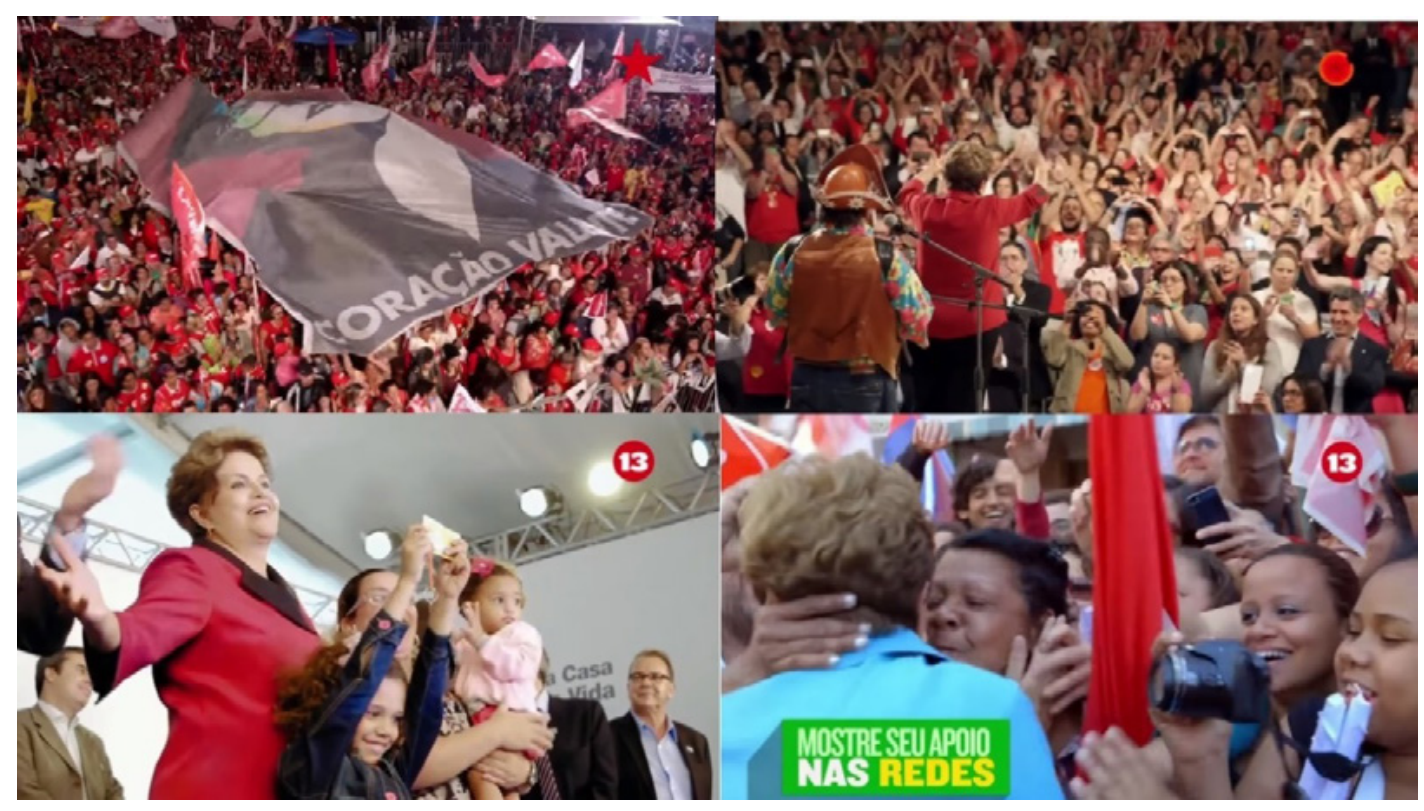

Figura 3. Montagem com imagens do HGPE de 24 de outubro

Fonte: https://www.youtube.com/watch?v=iOwP7f1pXKU.

Na ordem do visual, tem-se muitas pessoas de vermelho, em clara adesão às cores do partido da candidata, que também usa vermelho. Além disso, outras imagens ainda são dadas a ver, nas quais a candidata efetivamente interage com as pessoas e até é beijada, mostrando não só a adesão e legitimidade junto ao povo, mas também o carinho dessa identificação, afınal, o toque de corpos representa intimidade, proximidade, horizontalizando as relações entre esses sujeitos e fazendo com que a presidente, ali, seja alguém beijável. Em relação ao ethos constituído na ordem do não verbal, a candidata reconstrói todo o imaginário do representante querido do povo, eleitoral e fisicamente.

(2) O povo brasileiro sabe que não compactuo nem nunca compactuei com a corrupção. A minha história é um testemunho disso e sabe que farei o que for necessário, doa a quem doer. Toda vez que houver necessidade de investigar e de punir os que mexem com o patrimônio do povo, sou uma defensora intransigente da liberdade de imprensa, mas a consciência livre da nação não pode aceitar que mais uma vez se divulgue falsas denúncias no meio de um processo eleitoral, em que o que está em jogo é o futuro do Brasil.

Em (2), também de 24 de outubro, retomando a cenografia do incorruptível, o locutor afirma, dando ênfase a isso, que nunca compactuou com a corrupção e que fará o que for necessário, doa a quem doer. Mais uma vez, tal cenografia - observada em "nunca compactuarei com a corrupção", "farei o que for necessário", "doa a quem doer" - legitima 
o ethos de coragem, pois não importa a quem atinja, a candidata vai investigar e punir os que mexem com o patrimônio do povo. Assim, os efeitos de sentido são da ordem do castigo, pois haverá punições; ainda há o destaque para a palavra "intransigente" em relação à liberdade de imprensa, mesmo que esta seja usada para fazer falsas denúncias. Desse modo, o encadeamento de sentidos leva em direção à construção da imagem do candidato que não teme suas ações, pois elas estão corretas. Assim, ter coragem para punir aqueles que roubam do povo está entre os caracteres morais necessários ao bom político, o que gera adesão a esse mundo éthico de destemor frente àqueles que não só compactuam com a corrupção, como fazem isso por meio de mentiras na imprensa.

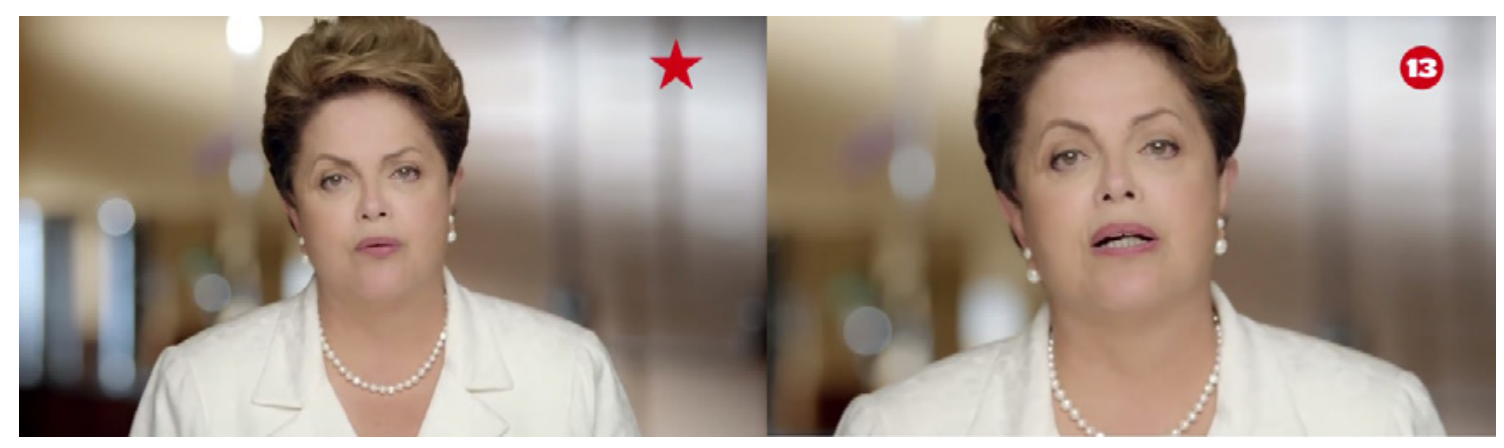

Figura 4. Montagem com imagens do HGPE de 24 de outubro

Fonte: https://www.youtube.com/watch?v=i0wP7f1pXKU.

Na ordem do não verbal, na figura 4, vemos a candidata trajando branco - cor que remete à clareza - com delicados colar e brincos de pérola. Com fala e gestual forte, semblante fechado, a candidata enfatiza as palavras, ao mesmo tempo em que levanta as mãos para pontuá-las. A partir do momento em que enuncia "a minha história", um close é dado em seu rosto, aproximando o telespectador, criando o efeito de realidade da conversa próxima, olhos nos olhos, como deve ser feita por alguém que enuncia que punirá os corruptos, doa a quem doer. Nesse sentido, a produção do ethos na ordem do visual, que é dinâmica na televisão e estática nos posts do Facebook, adquire outros contornos, pois apenas o corpo, agora, remete ao universo feminino, à docilidade da delicadeza de acessórios, enquanto todo o resto confere dureza aos efeitos de sentido em torno da coragem. Portanto, o ethos, ora de acolhimento do povo, ora de dureza, reafirma a dualidade da amável coragem sendo constituída, que, em alguns momentos, é tecida junto da figura do incorruptível e, em outros, junto de seu carisma com o povo.

Por fim, não é possível analisar a constituição do ethos de coragem sem mobilizar a questão do "Coração Valente". Um dos motes de campanha da candidata nas eleições de 2014 era "Dilma Coração Valente", lançado como jingle em um vídeo que circulou na

4 Publicado no YouTube em 20 de junho de 2014. 
televisão e YouTube, além de compartilhado em redes sociais pelos perfis oficiais da candidata. 0 jingle ${ }^{5}$, composto em forma de xote, tem como letra:

Dilma, coração valente, força brasileira, garra desta gente.

Dilma, coração valente, nada nos segura pra seguir em frente

Você nunca desviou o olhar do sofrimento do povo

Por isso, eu te quero outra vez

Por isso, eu te quero de novo

Você nunca vacilou em lutar em favor da gente

Por isso eu tô juntinho, do seu lado

Com você e Lula pra seguir em frente

Mulher de mãos limpas (tô com você)

Mulher de mãos livres (tô com você)

Mulher de mãos firmes, vamos viver uma nova esperança

Com muito mais futuro e muito mais mudança

Dilma, coração valente, força brasileira, garra desta gente

Dilma, coração valente, nada nos segura pra seguir em frente

O que tá bom, vai continuar

O que não tá, a gente vai melhorar (2x)

Coração valente!

No jingle, é possível observar o uso de palavras que remetem ao universo semântico de guerra e luta: "valente"; "força brasileira"; "garra"; "lutar". Não fortuitamente, tal trajetória semântica é trazida para o discurso da candidata de forma a remeter à luta da candidata na ditadura. Aos 15 anos, após ingressar no Colégio Estadual Central para cursar o ensino médio, Dilma teve contato com ideias contrárias à ditadura militar e integrou organizações, consideradas clandestinas, de esquerda. Sob o governo Médici, foi perseguida, presa e torturada no Departamento de Ordem Política e Social (DOPS) e de Operação Bandeirantes (OBAN), no estado de São Paulo. No vídeo, são trazidas imagens

5 Não nos cabe, neste momento, analisar com exaustão o jingle, uma vez que nosso material de análise é outro. 
de Dilma que corroboram a expressão "Coração Valente", no qual há uma imagem específica que circulou extensamente na mídia e retrata a candidata no momento de sua entrevista no período da Ditadura Militar do Brasil.

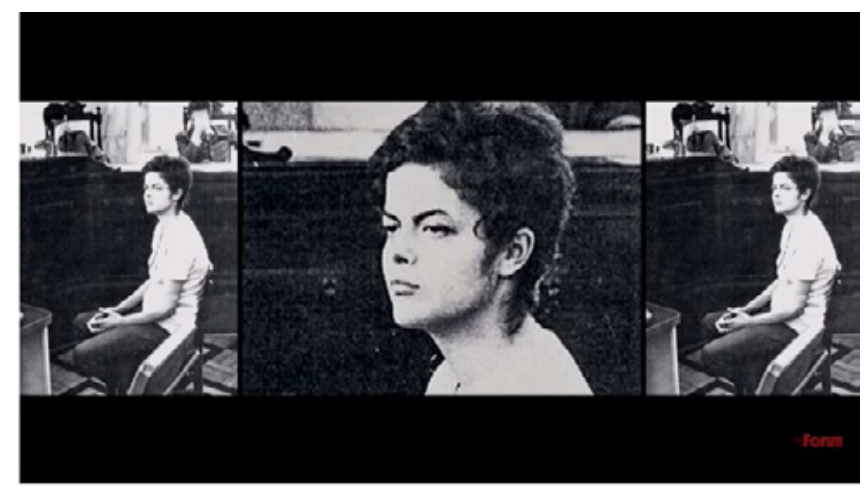

Dilma Coração Valente

359.679 visualizações

Figura 5. Dilma em entrevista na Ditadura Militar

Fonte: https://www.youtube.com/watch?v=3k8YQCSs8es.

O vídeo ainda apresenta a imagem que circulou por toda a campanha, emblema do slogan "coração valente":

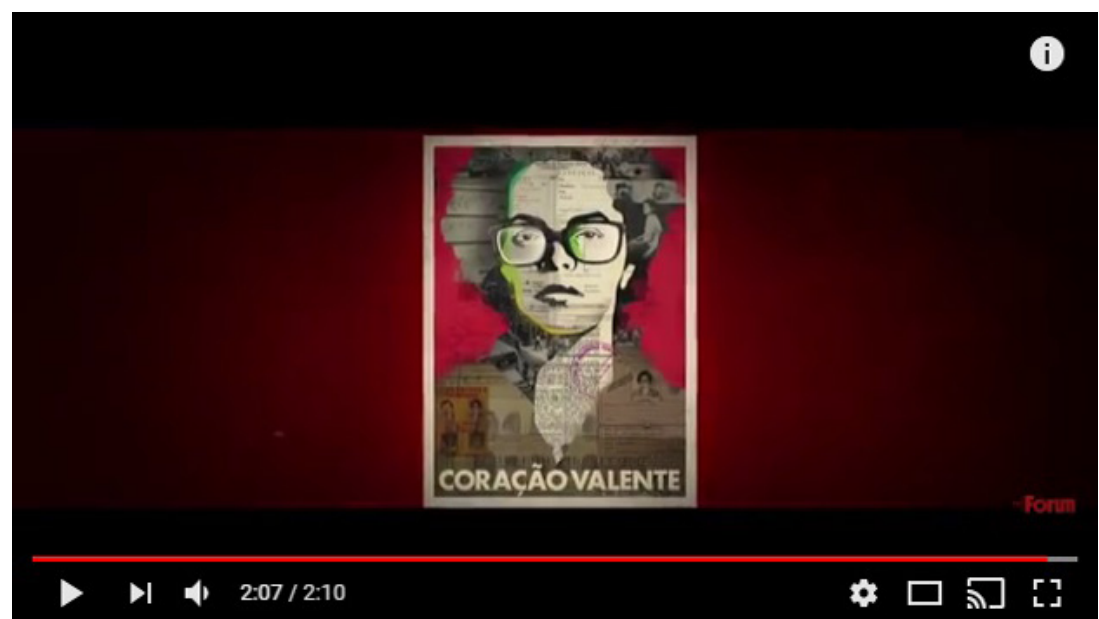

Dilma Coração Valente

359.679 visualizações

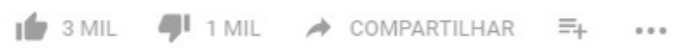

Figura 6. Dilma coração valente

Fonte: https://www.youtube.com/watch?v=3k8YQCSs8es. 
A imagem, que retoma a foto de Dilma no momento da prisão, traz uma composição de outras fotos e documentos que remetem também ao seu período de três anos sob o poder ditatorial. Há um fundo vermelho, que simbolicamente podemos relacionar à: (i) cor socialmente acordada para "coração"; (ii) cor da Bandeira Vermelha, representativa da esquerda e do comunismo, combatida pela ditadura; (iii) cor do Partido dos Trabalhadores ao qual a candidata pertence. No entorno dos óculos e da face, as cores da bandeira brasileira verde e amarela. No entanto, nesse percurso de sentidos, traçado pelo interdiscurso, é preciso recuperar que tal imagem, usada em toda campanha, teve uma versão preliminar - apenas com a foto estilizada e o fundo vermelho - divulgada em 2010 pela revista Época e que acompanhava matéria intitulada "O passado de Dilma. Documentos inéditos revelam uma história que ela não gosta de lembrar: seu papel na luta armada contra o regime militar". À época, os meios massivos brasileiros davam a circular discursos que ligavam Dilma a terrorismo e criminalidade. Sendo assim, a imagem, inicialmente divulgada em outro contexto, é ressignificada e atualizada, passando a construir sentidos em torno da luta e coragem da mulher que, com tristeza e passividade, fita o interlocutor.

Nesse jogo discursivo, a construção de imagens por meio da cenografia de mulher forte e lutadora engendra o ethos de coragem a ser constituído: a foto da mulher séria, no momento de sua prisão, passa a circular como símbolo de campanha. A desconstrução de "sexo frágil" dá lugar à figura da mulher que também luta, sofre e é agredida. Sob o signo de atributos femininos, surgem os convencionalmente atribuídos ao universo masculino, fazendo emergir um ethos no plano do não verbal, constituído a partir de signos e sentidos que compõem a imagem e recuperados por meio do interdiscurso imagético.

Passam, assim, a circular imagens durante a campanha que remetem e retomam o slogan: 


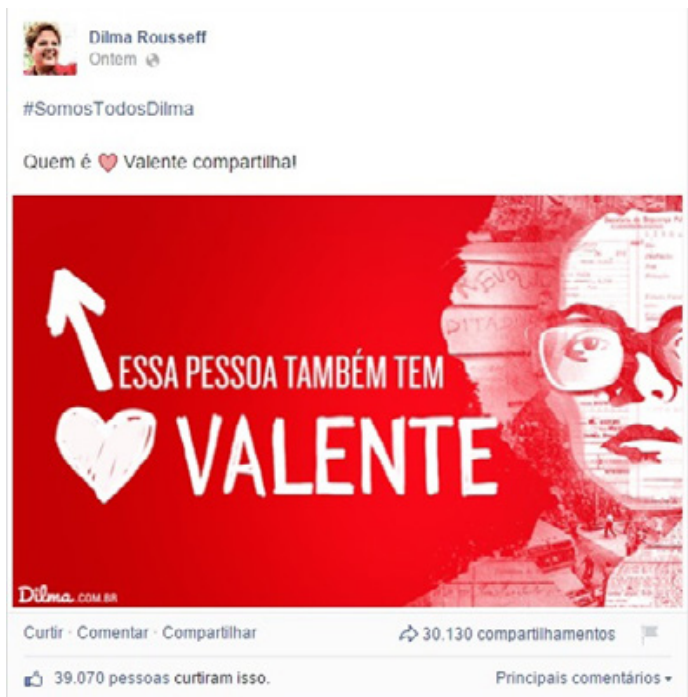

Figura 7. Post de Dilma Rousseff em 25 de outubro

Fonte: Perfil oficial no Facebook.

Ou mesmo a imagem associada a ele:

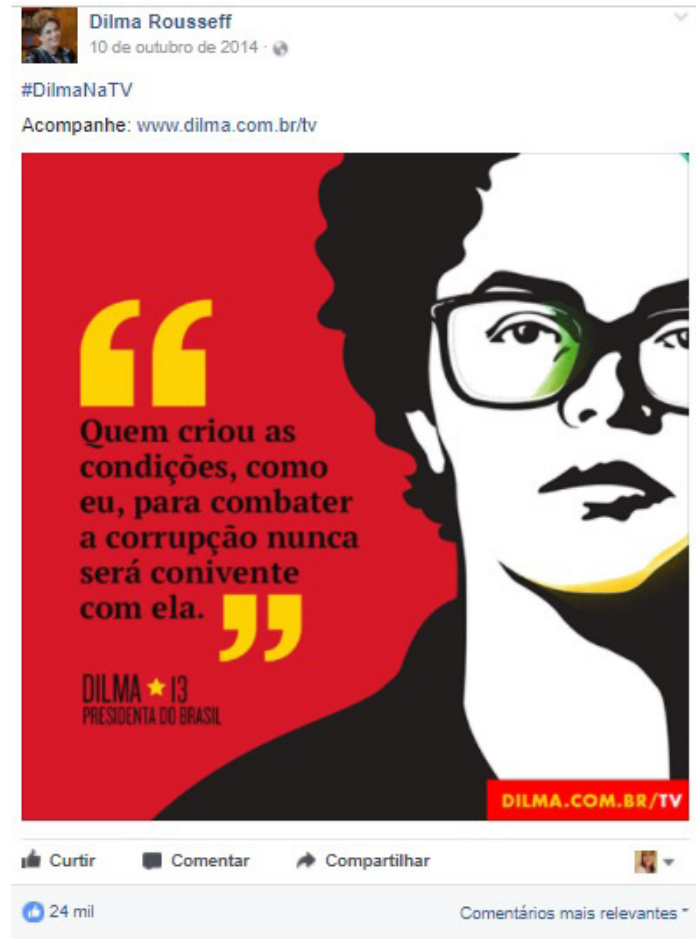

Figura 8. Post de Dilma Rousseff em 10 de outubro

Fonte: Perfil oficial no Facebook. 
Na figura 8, além da retomada imagética, temos o enunciado "quem criou as condições, como eu, para combater a corrupção, nunca será conivente com ela", atribuído à candidata. Dilma implementou no país a Operação Lava Jato. Desse modo, o locutor traz para a cena a cenografia do incorruptível, afinal, alguém que elaborou uma operação anticorrupção não tem meios de participar dela. Tal cenografia legitima e é legitimada na cena, construindo as bases do ethos de coragem: só alguém que possui coragem combateria a corrupção até mesmo em seu próprio partido. Ao ethos da ordem visual "coração valente", da mulher que não tem medo, da pessoa que tem coragem, soma-se o ethos mostrado, que irrompe do texto verbal. Dessa forma, força e coragem, em uma semiose de construção de ethé, delineiam um ethos discursivo de valentia.

\section{Conclusão}

Com a ressignificação de práticas ocorridas na era da hipermobilidade, metamorfoses foram impostas ao discurso político, inerentemente multimodal. A partir de sua multimodalidade, estudar o discurso político passou a ser, muito frequentemente, estudar a questão do ethos, uma vez que todo discurso está ligado a uma cena de enunciação que engendra a construção de imagens de si. Interessou-nos, aqui, desse modo, verificar a produção das imagens de si no discurso da candidata Dilma Rousseff em sua campanha de segundo turno na televisão e no Facebook.

Defendemos, portanto, que a complexidade na constituição do ethos discursivo de Dilma, advinda da relação entre o verbal e não verbal, está ancorada no discurso no feminino que perpassa as cenas, fazendo com que ao discurso político o feminino esteja ligado de maneira imanente, seja verbal ou não verbalmente. Justamente por essa complexidade de um sujeito político feminino, que traz para a cena signos específicos, além de seu próprio corpo no feminino, o ethos no plano imagético operou a partir de categorias muito mais diversas e dispersivas. Mas a dispersão também é produção de sentidos e tentamos, por meio do sintagma "amável coragem", constituir os efeitos de sentido que engendram toda a fabricação de imagens de si da candidata. A partir disso, pudemos observar a fabricação de uma imagem que trouxe para a cena cenografias variadas, tanto na ordem da coragem, quando na ordem da amabilidade, confluindo, em estado de semiose, dois sintagmas que se encontram no corpo da mulher: é preciso coragem para assumir o posto, mas não sem a docilidade de quem tem o apoio do povo. Na figura do "coração valente", a imagem da mulher que sofreu, mas ama; que foi torturada, mas sorri, encontra os alicerces do ethos de amável coragem.

Sendo assim, é preciso ainda destacar que não é possível mais estudar a questão do ethos como se este fosse uma etiqueta que se põe sobre o sujeito para adjetiválo: ethos amoroso, ethos de pai de família, ethos popular; antes disso, é preciso tomar a categoria em sua complexidade, levando em consideração a análise do plano verbal e não verbal, considerando sua multimodalidade intrínseca, dando atenção às novas 
práticas discursivas geradas a partir dos novos meios. Isso quer dizer que é preciso dar espaço para que a categoria seja engendrada por sua cena e não a forçar a caber em um rótulo adjetivado para o sujeito. O pesquisador que se interessa pela questão das imagens de si deve, antes, compreender a teatralidade da cena muito antes de "encaixotar" características morais aos atores políticos, deixando que a questão do ethos atue também em dispersão.

\section{REFERÊNCIAS}

BARREIRA, L. Imagens ritualizadas: apresentação de mulheres em cenários eleitorais. Campinas: Pontes, 2008.

BARREIRA, L. Chuva de Papéis: ritos e símbolos de campanhas eleitorais no Brasil. Rio de Janeiro: Relume Dumará, 1998.

MAINGUENEAU, D. Retorno crítico sobre o ethos. In: BARONAS, R. L.; CARREON, R. O.; MESTI, P. C. (org.). Análise do Discurso: entorno da problemática do ethos, do político e de discursos constituintes. Campinas: Pontes, 2016. p. 13-33.

MAINGUENEAU, D. La philosophie comme institution discursive. Limoges: Editora LambertLucas, 2015a.

MAINGUENEAU, D. Discurso e análise do discurso. São Paulo: Parábola Editorial, 2015b.

MAINGUENEAU, D. Ethos, cenografia, incorporação. In: AMOSSY, R. (org.). Imagens de si no discurso: a construção do ethos. São Paulo: Contexto, 2011. p. 16-28.

MAINGUENEAU, D. Doze conceitos em análise do discurso. São Paulo: Parábola Editorial, 2010.

MAINGUENEAU, D. A propósito do ethos. In: MOTTA, A. R.; SALGADO, L. (org.). Ethos discursivo. São Paulo: Contexto, 2008a. p. 11-29.

MAINGUENEAU, D. Gênese dos discursos. São Paulo: Parábola Editorial, 2008b.

MAINGUENEAU, D. Cenas da Enunciação. São Paulo: Parábola Editorial, 2008c.

MAINGUENEAU, D. Análise de textos de comunicação. São Paulo: Cortez, 2004.

MAINGUENEAU, D. Novas tendências em análise do discurso. Campinas: Pontes, Editora da Universidade Estadual de Campinas, 1997. 